\title{
Retraction
}

Mostafa Jalal* and Esmaeel Mansouri

\section{Effects of fly ash and cement content on rheological, mechanical, and transport properties of high-performance self-compacting concrete}

https://doi.org/10.1515/secm-2021-0064

received January 06, 2021; accepted October 31, 2021

Retraction of: Jalal M. Effects of fly ash and cement content on rheological, mechanical, and transport properties of high-performance self-compacting concrete. Sci Eng Compos Mater. 2012;19(4): 393-405.
This article has been retracted at the request of the Editor-in Chief, as it contains large portions of text that have been duplicated from the following article:

1. Siddique R. Properties of self compacting concrete containing class F flay ash. Mater Design. 2011;32: 1501-7.

\footnotetext{
* Corresponding author: Mostafa Jalal, Young Researchers Club, Science and Research Branch, Islamic Azad University, Tehran, Iran, e-mail: m.jalal.civil@gmail.com,mjalal@aut.ac.ir

Esmaeel Mansouri: Department of Civil Engineering, Razi University, Kermanshah, Iran
} 